\title{
Analysis of Horticultural Production Trends in Botswana
}

\author{
M. E. Madisa \\ Department of Crop Science and Production \\ Botswana College of Agriculture, University of Botswana \\ Private Bag 0027, Gaborone, Botswana
}

Tel: 267-365-0100 E-mail: memadisa@bca.bw

M. Obopile

Department of Crop Science and Production

Botswana College of Agriculture, University of Botswana

Private Bag 0027, Gaborone, Botswana

Tel: 267-365-0100Ｅ-mail: mobopile@gmail.com

\author{
Y. Assefa (Corresponding author) \\ Department of Crop Science and Production \\ Botswana College of Agriculture, University of Botswana, Gaborone, Botswana \\ Tel: 267-365-0100 E-mail: yosepharm@yahoo.com
}

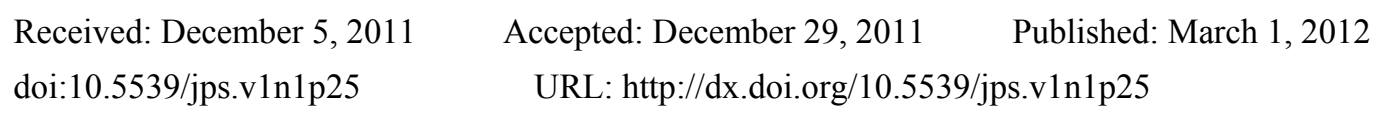

\begin{abstract}
An analysis of vegetable and fruit production trends in Botswana was carried out focussing on 1997 to 2009 cropping years. For vegetable production the results showed an increase in yield and total production from 1997 to 2009 . The area planted with vegetables accounted for only $3 \%$ of variation in yield indicating that the area planted with vegetables had no significant effect on yield during that period. The national demands for vegetables increased from 1997 to 2009, but imports started to decline in 2001. Regression analysis showed a significant decline in imports as total production increased. Total production accounted for more than $50 \%$ of variation in imports indicating that a significant proportion of national demand was met by local production. Total fruit production increased from 3000 to over 9000 tons from 2003 to 2008 but declined in 2009. Yield increased twofold from 2003 to 2005 but declined by more than $50 \%$ at the end of 2009 . Regression analysis showed a significant decrease in yield as area planted increased; indicating a decrease in productivity. The national fruit production was surpassed by demand during 2003 to 2009 revealing a deficit in fruit production. The total imports of fruits declined significantly as total production increased suggesting that some of the demands for fruits were catered for by local production. These results suggest that famers need to be trained on good management of crops so that productivity can increase with increase in area planted to horticultural crops.
\end{abstract}

Keywords: Total production, Fruit, Vegetables, Imports, Trends, Demands

\section{Introduction}

In Botswana, the supply of horticultural produce to the formal market is mainly controlled by big companies. However, most local farmers involved in horticulture practice peasant farming for consumption and for retail sale in the informal market, local communities and street corners in the cities. These farmers are mainly constrained by different factors which include; pests, water and shortage of basic farm inputs like seed and fertilizers. They also have limited knowledge of the standard methods of production required to satisfy the genetic requirement of improved seeds and have insufficient access to the formal market. Horticultural produce by these small-scale farmers however, is increasing over the past decade; though this has fluctuated significantly 
mainly due to the dependence on seasonal unreliable rainfall and poor farm management practices (Madisa et al., 2010b). A major trend is that the number of literate households in the small-scale category has been increasing (Madisa et al., 2010b) and this will have a positive impact on the sustainable growth in the sector (Dogliotti et al., 2005; Kuponiyi \& Adewale, 2008)

Horticultural production has been indicated as a sector that can provide real opportunities for enhancing farm incomes and reducing poverty in developing countries (Weinberger \& Lumpkin, 2005). Botswana government support for commercial agriculture has been extended in pursuit of the national objectives of economic diversification, employment creation and income generation (Seleka, 2007). The diversification of agriculture is considered an important strategy for agricultural development in Botswana and importance of horticulture crops as a means of diversification and creation of employment opportunities is recognized.

Public support for improvement of horticultural production has been shown by introduction of farm level financial incentive schemes that included Financial Assistance Policy (FAP) and currently Citizen Entrepreneurial Development Agency (CEDA) (Rebaagetse, 1999; Madisa et al., 2011). The level of improvement of horticultural production can be determined by substantial increase in area planted to horticultural crops and increase output and yield at farm level (Seleka, 1999). The complexity and retail-level concentration of the fresh-produce business, however, requires more than production efficiency. To compete more effectively in the local and regional fresh produce markets, Batswana growers and traders should understand the market windows open for their products, shadow window competition, market-access conditions and effective management practices. Informed production and supply-chain management should replace the current shipper-controlled, cost-driven supply chain. There should be greater focus on developing demand/pull, value-driven supply chains and recognition that the flow of information along the supply chains is as important as the flow of products from the production areas to the market place. Analysis of trends in horticultural production as function of time has been used to measure the productivity of agricultural sectors in Botswana (Seleka, 1999). Production trends show fluctuations in production revealing years when production increased or decreased as a results of various factors that influence horticultural production. Annual reports from department of Agriculture and Central Statistics Office show the yearly variation in area allocated, yield, demand and supplies of vegetables and fruits. The number and demography of farmers actively involved in medium scale horticultural production has also changed (Madisa et al., 2010a). However, very little is in fact known about the trend in the quantity of horticulture produces, horticultural produce imported to the country and the balance on supply and demand. This paper discusses the trend in land allocated to horticulture, total vegetable and fruit production and import of horticultural crop to Botswana.

\section{Methodology}

The data on area cultivated and yield were obtained from Division of Horticulture annual reports of the Department of Crop Production in the Botswana Ministry of Agriculture, The first and last authors participated in the collection and compiling of the annual reports used in this study. The study focussed on data collected from 1997 to 2009 for vegetable production and 2003 to 2009 for fruit production. Data on import and consumers' demand were obtained from Central Statistics Office (CSO). Productivity was calculated using excel spread sheet. The data was analysed using PROC REG in SAS (SAS Institute, 2003) to test for relationship between area planted and production and between production and imports.

\section{Results}

\subsection{Vegetable production trends}

The trends in area planted, total production and productivity of vegetable crops in Botswana are shown in Table 1. The results showed that the area planted to vegetables increased twofold from 1997 to 2006 but declined slightly in 2009. Total production increased almost 5 times from 1997 to 2009. On average, productivity (yield ${ }^{\text {-ha }}$ ) increased twofold from 1997 to 2009 . The area planted to vegetables accounted for only $3 \%$ of variation in yield indicating that the area planted to vegetables had no significant effect on yield (Fig. 1).

[Insert Table 1 here]

\subsection{Imports and demand}

The national demands for vegetables continued to increase from 1997 to 2009, but imports started to decline in 2001 (Fig. 2). The period of decline in imports coincided with a period when area planted, total production and productivity started to increase significantly (Table 1). This observation was confirmed by regression analysis which showed a significant decline $(\mathrm{P} \leq 0.05)$ in imports as total production increased (Fig. 3). Total production 
accounted for more than $50 \%$ of variation in imports indicating that a significant proportion of national demand was met by local production (Fig. 3).

[Insert Figure 1 here]

[Insert Figure 2 here]

[Insert Figure 3 here]

\subsection{Fruit production trends}

The data on fruit production, area planted and yield is based on records from 2003 to 2009 (Table 2). The total fruit production increased from 3000 tons to over 9000 tons from 2003 to 2008 but declined in 2009 (Table 2). The area planted with fruit trees remains at 300 hectares from 2003 to 2005 and then tripled at the end of 2009 . Yield per hectare increased twofold from 2003 to 2005 but declined by more than $50 \%$ at the end of 2009. The total area planted with fruit trees accounted for more than $50 \%$ of the variation in yield per hectare. Analysis of data showed a significant decrease $(\mathrm{P} \leq 0.05)$ in yield as area planted increased; indicating that some of the land planted with fruit trees was not productive (Fig. 4).

[Insert Table 2 here]

[Insert Figure 4 here]

\subsection{Imports and demand}

The national fruit production was surpassed by demand during 2003 to 2009 (Fig. 5) indicating a deficit in fruit production. The total imports ranged from 1500 to 1800 tons annually while demand ranged from 2250 to 2600 tons during 2003 to 2009. Regression analysis showed a significant relationship between total production and imports (Fig. 6). The total imports of fruits declined significantly as total production increased suggesting that some of the demands for fruits were catered for by local production.

[Insert Figure 4 here]

\section{Discussion}

\subsection{Horticultural production trends}

The current results showed a significant increase in annual horticultural production in Botswana from 1997 to 2009. An increase in horticultural production has been attributed to substantial public support, geared at diversifying the sector. Farm level financial assistant incentives like Financial Assistance Policy (FAP) which operated from 1982 to 2000 (Rebaagetse, 1999), and the current Citizen Entrepreneurial Development Agency (CEDA) introduced in 2002 which have attracted people to venture into vegetable production as a business. The current production trends were observed by previous studies (Madisa et al., 2010a; Obopile et al., 2008; Anon, 2009). However, unlike the previous studies we have done analysis of the trends and related production to yield and imports to total production. The study revealed that for vegetable production, a significant loss of productivity occurred as shown by no significant relationship between increases in area cultivated to crops to yield per hectare. In fruit production there was a significant decline in productivity as the area cultivated increased. These results corroborated that of Seleka (1999) who showed that the increase in area cultivated did not improve crop output but rather resulted in decline in productivity per year during the study period. The contributing factors to low productivity in horticultural production were not investigated in this study. However previous studies have pointed to a number of production constraints.

These constraints included pests, lack of labour, water shortage, market accessibility, lack of capital, maintenance costs, transport, flood, shortage of land and inaccessibility of production inputs, poor farm management and lack of training (Seleka, 1999; Obopile, 2008; Madisa et al., 2010a). It is plausible that some of these constraints could have contributed to low productivity especially pests and poor management. Most farmers ventured into vegetable production were assisted financially through banks and government schemes, therefore lack of capital inputs and related constraints may not be responsible for low productivity. It could rather be due to lack of labour, water stress and lack of skills by farmers on managing their vegetable farms and orchards. Madisa et al. (2010a) and Seleka (1999) also ranked crop pests, lack of labour water stress and poor management among the top constraints mentioned by farmers.

\subsection{Imports and demand}

The results of this study showed a decline in imports as total production increased indicating that local production offset some of the local demand for horticultural products. The decrease in imports as total production increased can be attributed to import substitution by government that is implemented through import 
permit system, thereby stimulating farmers to increase production. While the annual total production increased annually from 1997 to 2009 , it has not met annual demands for horticultural products. These results confirm the national reports that showed that the 2008/2009 national demand for vegetable crops was estimated at 50,000 metric tons for vegetables, while local production for the same year was 3100 tons. During National Development Plan 9 (NDP9) production per demand increased from $20 \%$ to $40 \%$, while production for 2008/09 satisfied only $51 \%$ of the national requirement (Anon, 2009). Seleka (2007) reported that imports in Botswana generally surpassed domestic production, and the ratios of net imports to total demand were high and have increased over time.

These results and those of previous studies suggest that an improvement in crop productivity is more important than just increasing area planted crops. The emphasis therefore should be on training farmers on good management of crops so that crop productivity can increase with increase in area planted to horticultural crops. An improvement in productivity will reduce net importation of horticultural products and move towards reduction of relying on imports.

\section{References}

Anon. (2009). Annual Report - 2008/2009. Division of Horticulture and Beekeeping. Ministry of Agriculture, Gaborone Botswana.

Dogliotti, S., Ittersum, M.K.van., \& Rossing, W.A.H (2005). A method for exploring sustainable development options at farm scale: a case study for vegetable farms in south Uruguay. Agricultural Systems, 86(1), 29-51. http://dx.doi.org/10.1016/j.agsy.2004.08.002

Kuponiyi, F.A., \& Adewale, J.G. (2008). The use of safety devices in adoption of agro-chemicals by rice farmers in Obafemi-Owode Local Government Area of Ogun State. African Journal of Food, Agriculture, Nutrition and Development, 8(4), 427-440.

Madisa, M. E., Assefa, Y., \& Obopile, M. (2010a). Assessment of Production Constraints, Crop and Pest Management Practices in Peri-Urban Vegetable Farms of Botswana. The Egyptian Academic Journal of Biological Science, 1, 1-12.

Madisa, M. E., Assefa, Y., \& Obopile, M. (2010b). Crop diversity, extension services and marketing outlets of vegetables in Botswana. The Egyptian Academic Journal of Biological Science, 1(1), 13-22.

Madisa, M. E., \& Assefa, Y. (2011). Impact of government financial incentives on peri urban vegetable production in Botswana. Journal of Horticulture and Forestry, 3(8), 264-269.

Obopile, M., Munthali, D. C., \& Matilo, B. (2008). Farmers' knowledge, perceptions and management of vegetable pests and diseases in Botswana. Crop Protection, 27, 1220-1224. http://dx.doi.org/10.1016/j.cropro.2008.03.003

Rebaagetse, M. J. (1999). An Overview of the Performance of Agricultural Projects Funded through the Financial Assistance Policy (FAP) for the period 1982-1998. Ministry of Agriculture, Gaborone. Botswana.

SAS Institute. (2003). SAS users guide: statistics. SAS Institute, Cary, NC.

Seleka, T. B. (1999). The performance of Botswana's traditional arable agriculture: growth rates and the impact of the accelerated rainfed arable programme (ARAP). Agricultural Economics, 20, 121-133. http://dx.doi.org/10.1016/S0169-5150(98)00084-X

Seleka, T. B. (2007). Welfare impacts of import controls on Botswana's horticulture. Agricultural Economics, 36, 305-311. http://dx.doi.org/10.1111/j.1574-0862.2007.00208.x

Weinberger, K., \& Lumpkin, T.A. (2005). 'Horticulture for Poverty Alleviation. The Unfunded Revolution'. AVRDC Working Paper Series, No.15 Taiwan: The World Vegetable Centre. 
Table 1. Area and production of vegetables crops in Botswana from 1997-2009

\begin{tabular}{cccc}
\hline Years & Production (Tons) & Area (hectares) & Productivity (yield ha $^{-1}$ \\
\hline $1997 / 1998$ & 6900.00 & 407.85 & 16.92 \\
$1998 / 1999$ & 9198.00 & 496.75 & 18.52 \\
$1999 / 2000$ & 3546.00 & 545.45 & 6.50 \\
$2000 / 2001$ & 7289.00 & 1060.11 & 6.88 \\
$2001 / 2002$ & 8080.00 & 671.35 & 12.04 \\
$2002 / 2003$ & 13406.00 & 462.34 & 29.00 \\
$2003 / 2004$ & 15874.09 & 904.57 & 17.55 \\
$2004 / 2005$ & 18179.63 & 982.36 & 18.51 \\
$2005 / 2006$ & 30762.95 & 1036.00 & 29.69 \\
$2006 / 2007$ & 24076.16 & 882.45 & 27.28 \\
$2007 / 2008$ & 31985.00 & 925.21 & 34.57 \\
$2008 / 2009$ & 31150.00 & 830.00 & 37.53 \\
\hline
\end{tabular}

Table 2. Area and production of fruit trees in Botswana from 2003-2009

\begin{tabular}{lccc}
\hline Year & Productions (tons) & Area (hectares) & Productivity $($ yield ha \\
\hline $2003 / 2004$ & 3388.05 & 340.79 & 9.94 \\
$2004 / 2005$ & 5212.49 & 311.40 & 16.74 \\
$2005 / 2006$ & 6686.79 & 337.97 & 19.79 \\
$2006 / 2007$ & 8118.99 & 683.99 & 11.87 \\
$2007 / 2008$ & 9551.18 & 1030.00 & 9.27 \\
$2008 / 2009$ & 7850.00 & 1030.00 & 7.62 \\
\hline
\end{tabular}

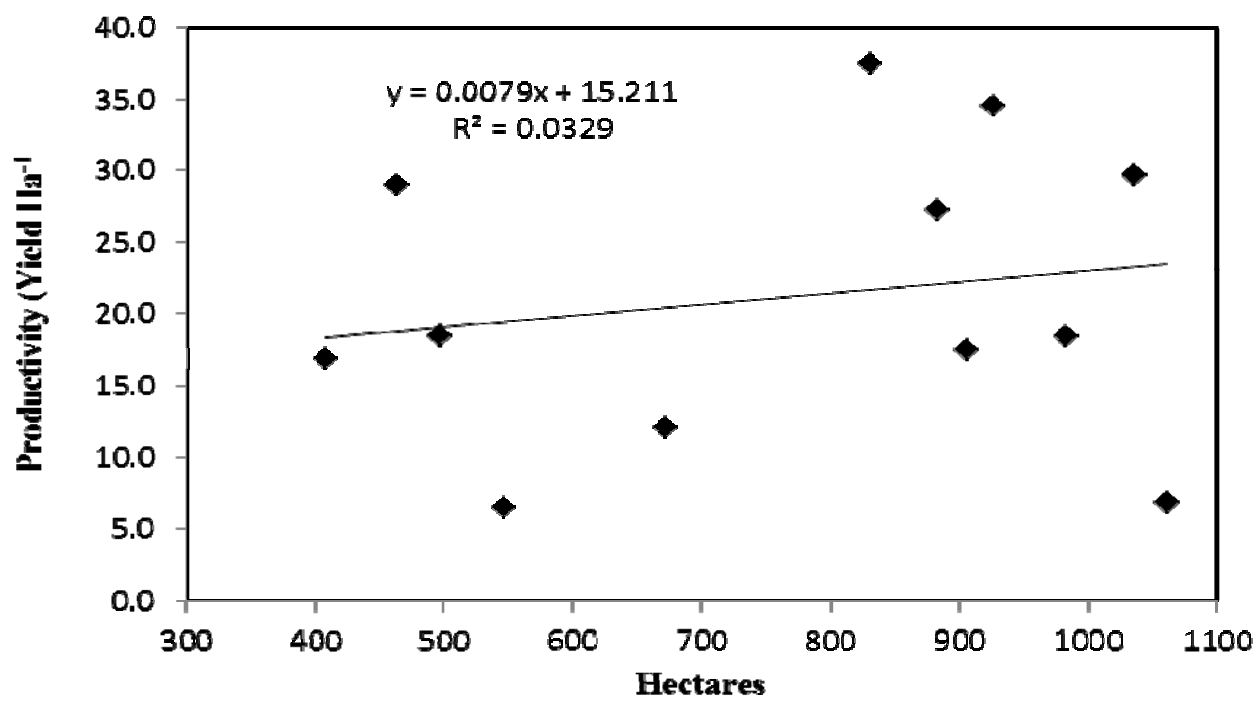

Figure 1. Relationship between area planted and yield (data averaged acrossed years) 


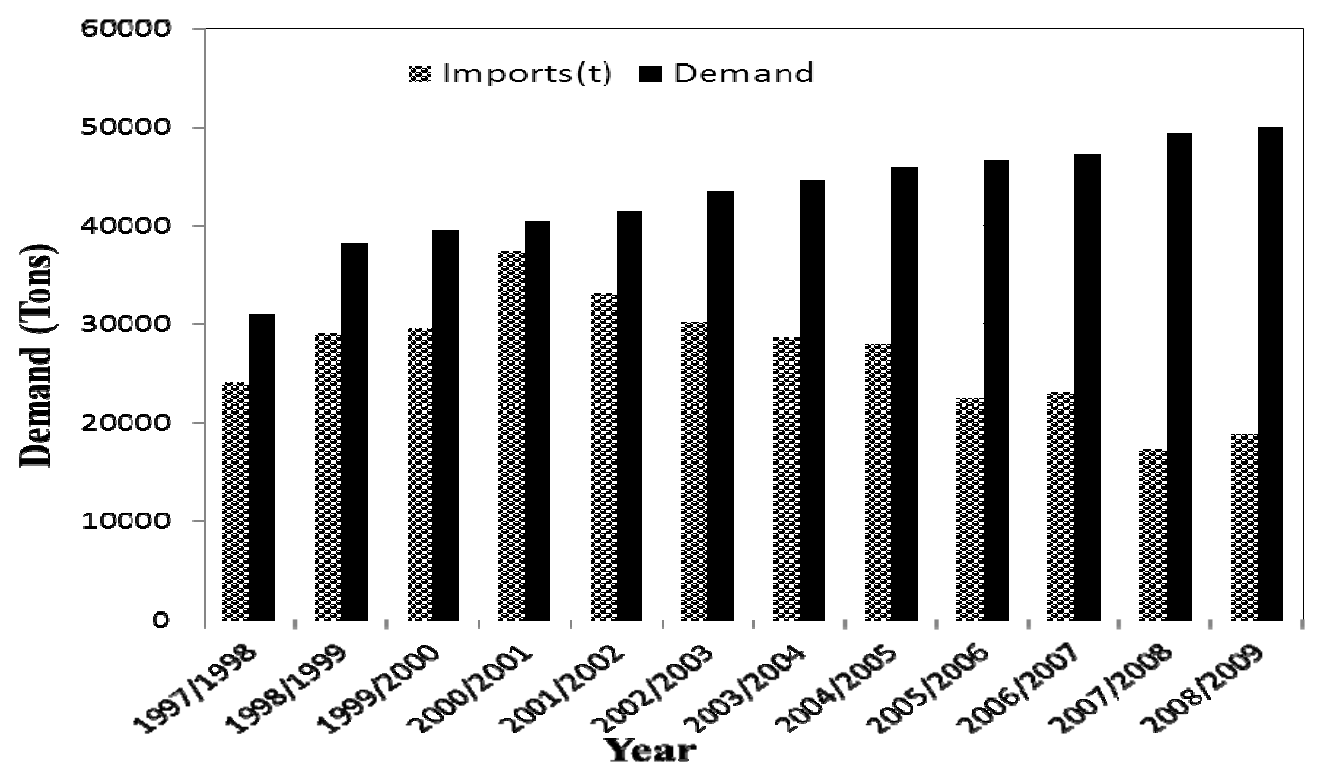

Figure 2. Imports (Tons) and demands for vegetable produce from 1997 to 2009

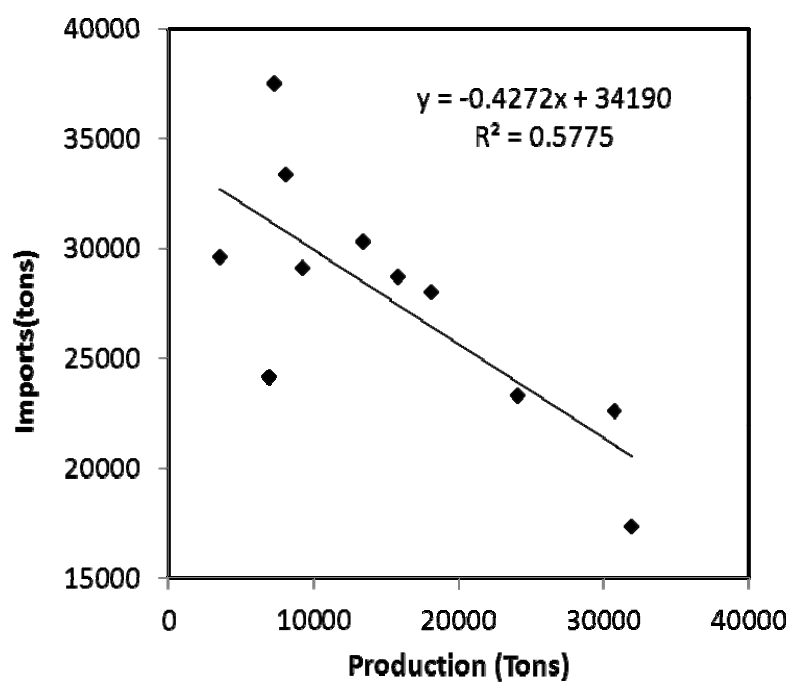

Figure 3. Relationship between total production and imports of vegetable produce (data averaged across years) 


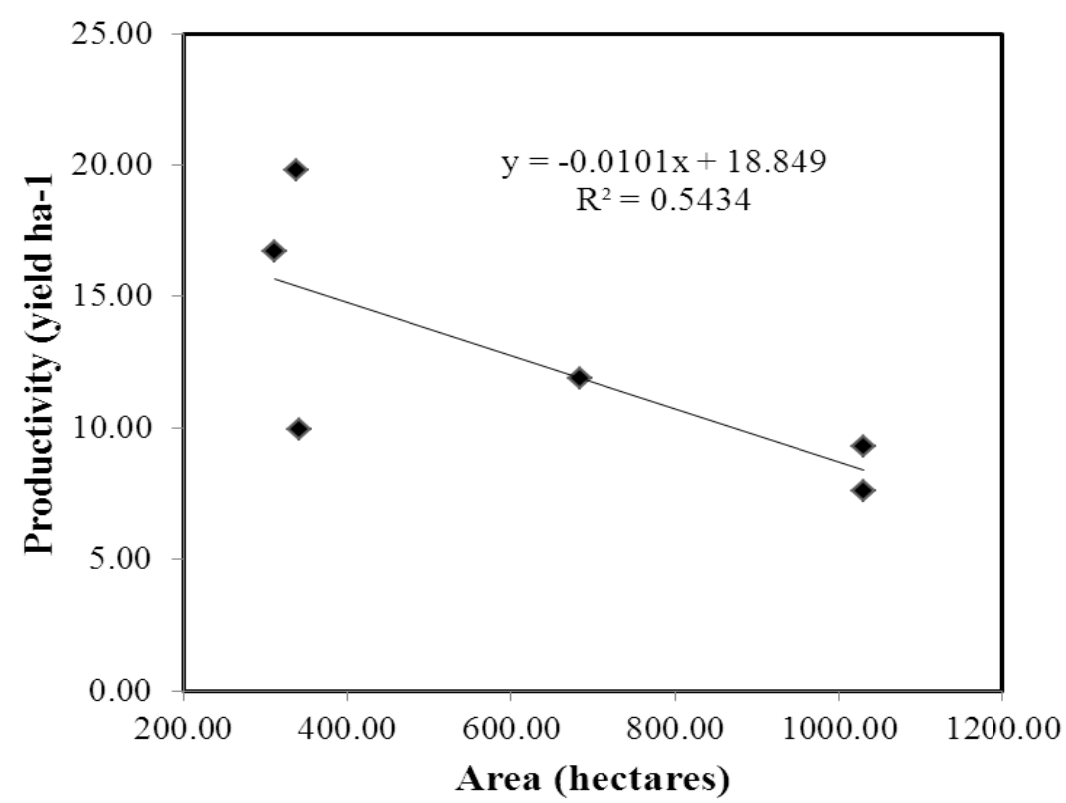

Figure 4. Relationship between area planted with fruit trees and yield (data averaged acrossed years)

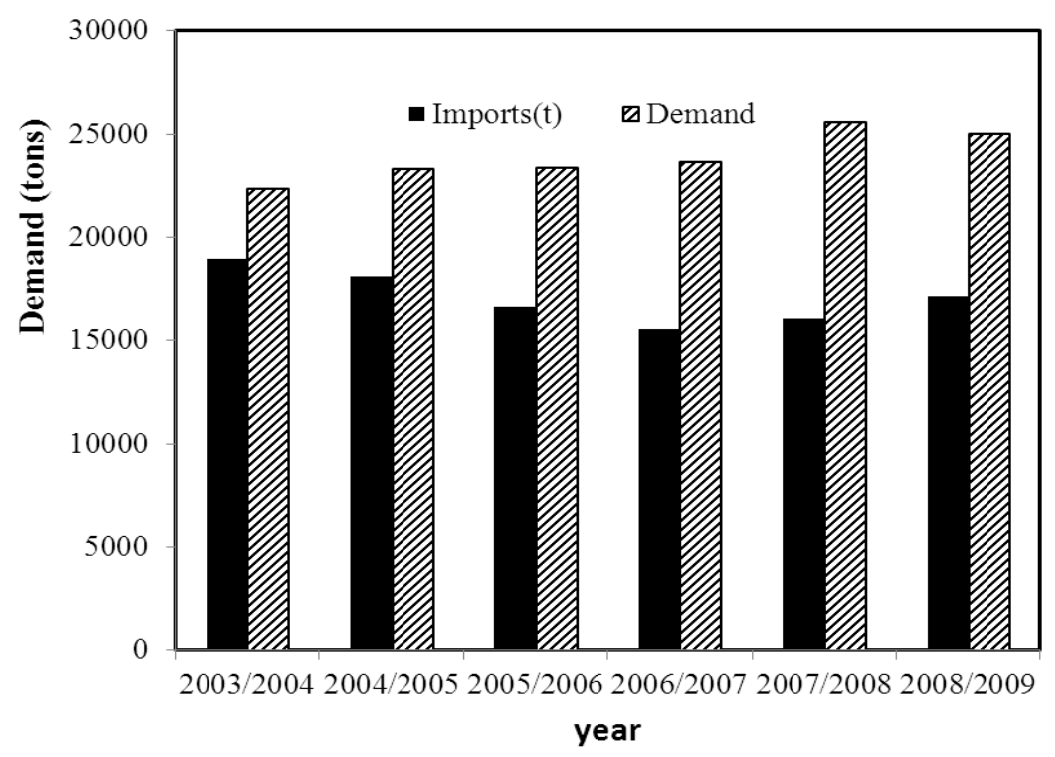

Figure 5. Imports and demands for fruits from 1997 to 2009 


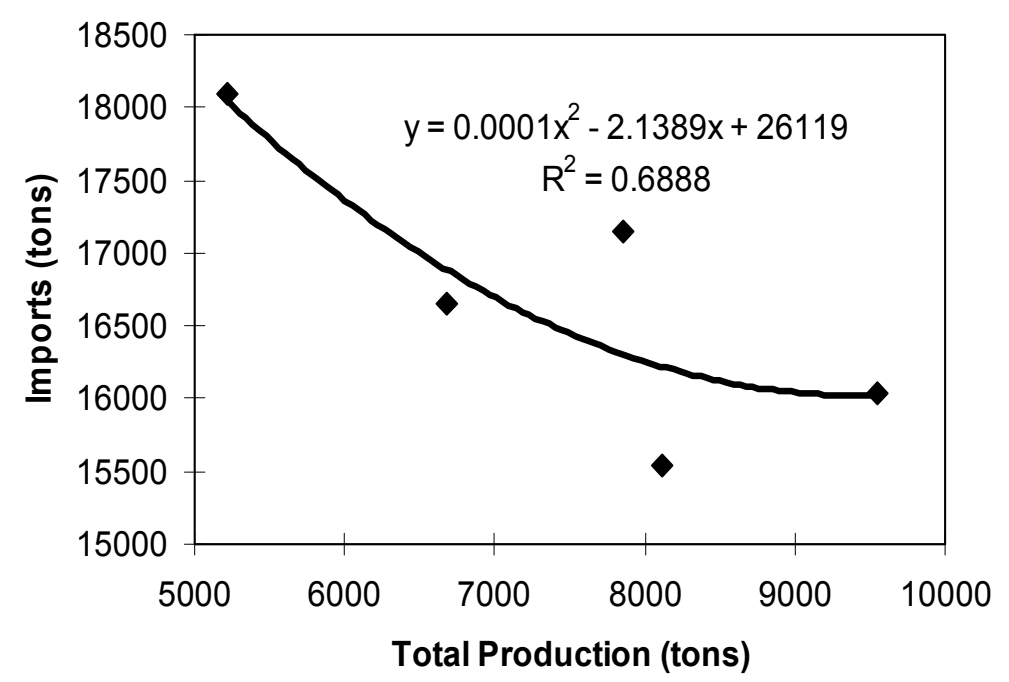

Figure 6. Relationship between total production and imports of fruits (data averaged across years) 